\title{
Effect of changes in state funding of higher education on higher education output in South Africa: 1986-2007
}

\author{
PIERRE DE VILLIERS AND GERT STEYN
}

Stellenbosch Economic Working Papers: 24/08
KEYWORDS: HIGHER EDUCATION, FINANCING, SUBSIDY FORMULA, EDUCATION OUTPUT
JEL: H40; $122 ; 123$

PIERRE DE VILLIERS DEPARTMENT OF ECONOMICS UNIVERSITY OF STELLENBOSCH

PRIVATE BAG X1, 7602 MATIELAND, SOUTH AFRICA

E-MAIL: APDV@SUN.AC.ZA
GERT STEYN

INSTITUTIONAL RESEARCH AND PLANNING DIVISION UNIVERSITY OF STELLENBOSCH PRIVATE BAG X1, 7602 MATIELAND, SOUTH AFRICA E-MAIL: GSTEYN@SUN.AC.ZA

\section{$\$$}




\title{
Effect of changes in state funding of higher education on higher education output in South Africa: 1986-2007 \\ PIERRE DE VILLIERS AND GERT STEYN
}

\begin{abstract}
During the last two decades state funding of higher education in South Africa has decreased substantially (especially if public expenditure of HE as a percentage of GDP is used as a yardstick). HE institutions were forced to increase tuition fees and rely more on the third income stream to balance their books. In the process increases in instruction/research staff did not keep up with the increase in student numbers.

During the period 1986-2003 qualifications awarded to students per full-time equivalent instruction/research staff member increased over time - indicating greater efficiency of the HE sector in delivering more teaching output. High-level research in the form of publication units in accredited journals, however, stagnated during this period. In recent years until 2007, however, publications in accredited journals increased substantially. This was mainly the result of broadening the number of accredited journals by the Department of Education. In this paper two indicators, linked to the current funding formula for higher education, to measure academic output of HEls are defined and applied to the output of institutions for the period since 2002. It is concluded that there is large variability between HEIs as far as teaching and research output are concerned. A cause for concern is that the majority of the research is conducted by just a few HE institutions.
\end{abstract}

Keywords: Higher education, Financing, Subsidy formula, Education output JEL codes: H40; 122; 123 


\section{INTRODUCTION}

During the twentieth century government participation in the economy and also public spending on education increased considerably, which can partly be explained by the development of the human capital model in the 1960s. Many studies indicated that it is profitable for both the private and public sectors to invest in education. A lot of funds were invested in education, but the results were not always as promising as everybody expected them to be. During the last twenty years or so governments have cut back on their spending on higher education (HE). South Africa was no exception and public expenditure on $\mathrm{HE}$ decreased quite substantially (especially if public expenditure on HE as percentage of GDP is taken as the yardstick).

This paper will investigate the South African HE sector's performance, as far as teaching output and research are concerned, for the period 1986-2007. Firstly, the period 1986-2003, when the South African Post-Secondary School (SAPSE) subsidy formula was used to fund HE institutions, will be examined. In 2004 the HE landscape in South Africa changed completely with the merging of institutions, which reduced the 36 HE institutions to 23, simultaneously with the introduction of the New Funding Framework (NFF). The period since 2004 will therefore be analysed separately.

\section{TRENDS IN FUNDING OF HE}

\subsection{Public funding of HE}

There are many studies which indicate that it is profitable to invest in education - both for the individual and the state (see comprehensive summary of 98 studies in Psacharoupoulos and Patrinos, 2002). Despite these findings, public expenditure on higher education in South Africa decreased from 0.86\% of GDP in 1987 to 0.66\% in 2006 (De Villiers and Steyn, 2007: 140). It must be mentioned, however, that during the years 2007-2009 more than R3.6 billion in total is and will be provided on an earmarked ad hoc basis for infrastructure development and for increased student enrolment as part of the JIPSA initiative (Ministry of Education, 2007). Public funding of HE in South Africa lags behind the rest of the world. In 2001 the total public expenditure on higher education institutions and higher educational administration as a percentage of the GDP by local, regional and national governments for 84 countries was $0.81 \%$ (UNESCO Institute of Statistics, 2004: Table 11). In 2000 public 
expenditure on HE was $0.90 \%$ of GDP for 29 OECD countries (OECD, 2004). De Villiers and Steyn (2007) made some forecasts about future public funding of HE in South Africa, and according to their scenarios the chances are slim that there will be much financial relief (if any) for the HE sector in the foreseeable future and the above-mentioned decreasing trends are bound to continue.

\subsection{Change in composition of income of HE institutions}

This sub-section focuses only on the period 1986-2003, since the structure of HE in South Africa changed completely after 2004. ${ }^{1}$ State appropriations per weighted full-time equivalent university student (WFTES ${ }^{2}$ ) decreased from R25 125 in 1986 to R16 119 in 2003 - a decrease of 36\% (in constant 2000 prices). This forced these institutions to generate funds from other sources, via higher tuition fees and/or the third income stream, mainly in the form of earmarked research allocations by state agencies, contract research and philanthropic contributions. As a result of this, real tuition fee income per WFTES for universities increased by 49\% from R6 068 in 1986 to R9 030 in 2003. State appropriations dropped from $53 \%$ of the income for universities in 1986 to just $41 \%$ in 2003, while tuition fees increased from less than $13 \%$ to $23 \%$ of their income during the same period. State appropriations to technikons dropped by 43\% in real terms from 1987 to 2003, but tuition fees increased during the same period by no less than 85\% from R3 812 to R7 056 (in constant 2000 prices). This decreased the relative importance of state appropriations to the income of technikons from $68 \%$ to $52 \%$ and tuition fees increased from less than $12 \%$ to approximately $30 \%$ of their income from 1987 to 2003. No clear trends were observed for the third income stream for HE institutions.

\footnotetext{
${ }^{1}$ See a more detailed summary of certain aspects in De Villiers and Steyn (2006) and a thorough discussion of this section with all the data attached in a report for the CHE by Steyn and De Villiers (2006).

${ }^{2}$ The FTE value of a full-time student who takes all the modules of an academic programme in a specific year will normally be about 1 , but could vary depending on specific module choices. Weighted FTE students (WFTES) for an institution are equal to FTE contact tuition students plus $0.67 \times$ FTE distance tuition students (because the educational costs of distance education students are assumed to be $67 \%$ of the costs of full-time students).
} 


\subsection{Funding models of HE in South Africa}

Four subsidy formulas have been used in the HE system of South Africa. ${ }^{3}$ Although the Holloway formula (HF) that was introduced in 1953 and the van Wyk de Vries formula (vWdV) that was implemented in 1977 are shown in Figure 3, they will not be discussed. The South African Post-Secondary Education (SAPSE) formula was introduced in 1984, revised in 1993, and was used until 2003. The New Funding Framework (NFF) was implemented in 2004 and is still in use.

The SAPSE formula was based on the assumption that students are the best judges of their own welfare and are the best informed to decide for which academic programme to enrol. The formula was thus enrolment driven, with funding following students as they enrol at institutions of their choice. In that sense it can be considered a market-driven formula. As indicated in Figure 1, higher education institutions (HEIs) received a subsidy based on the FTE number of students in Natural Sciences and Human Sciences (input driven) respectively, as well as the number of successful (degree credit) students for Natural Sciences and Human Sciences (output driven). The input and output components were weighted equally. Institutions also received additional subsidies for FTE growth in students in the two fields of study (input driven) as well as for approved publications generated by institutions (output driven). This resulted in inputs and outputs being weighted about equally within this subsidy formula.

\section{Figure 1}

\section{Schematic representation of SAPSE formula ${ }^{1)}$ for universities and technikons for year $n$}

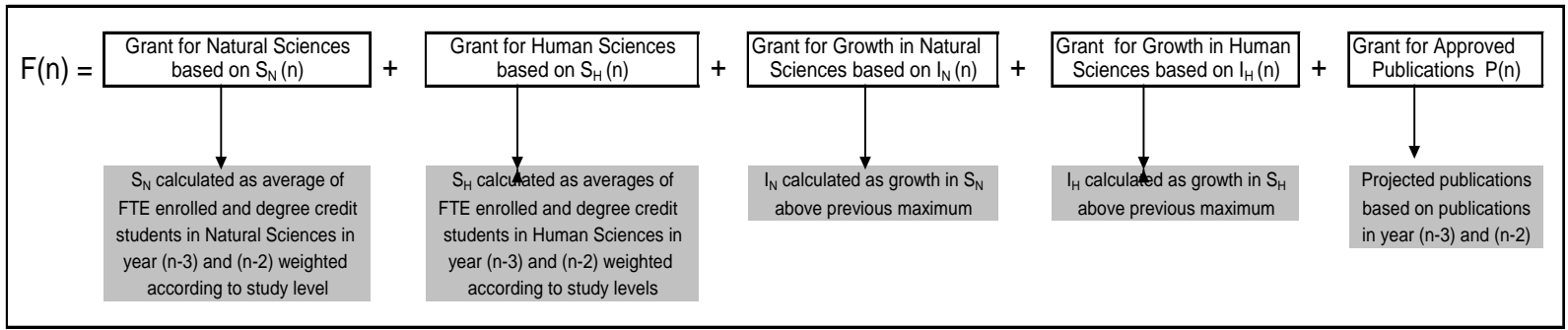

1) For the sake of simplicity the small allocations for FTE students as a result of their residential status have been omitted.

In 1993 the SAPSE formula was revised and the subsidy per student in Natural Sciences was increased relative to the subsidy per student in the Human Sciences. Restrictions on student

\footnotetext{
${ }^{3}$ See Steyn and De Villiers (2006: Section 2) and Steyn and De Villiers (2007) for an in-depth discussion of the funding formulas used in South Africa. The merits or demerits of the different funding formulas fall outside the scope of this paper.
} 
growth were implemented and only a projected increase in $S_{N}$ and $S_{H}$ of $2.5 \%$ for contact and $5 \%$ for distance tuition (universities) and $6 \%$ for contact and $8 \%$ for distance tuition (technikons) was subsidised. As with the 1984 SAPSE formula, about 50\% of the subsidy was based on output measures.

The New Funding Framework (NFF) was implemented in 2004. With this formula the government endeavours to influence the size and shape of the HE sector. This funding regime consists of a subsidy formula which in 2004 contributed about $87 \%$ of the allocations and a set of earmarked allocations (NSFAS, foundation programmes, restructuring, etc.) contributing the other $13 \%$. As illustrated in Figure 2, the subsidy in year $n$ consists of 4 block grants, based on student enrolments in year (n-2), qualifications awarded in year (n-2), research output in year (n-2) and certain other institutional data for year (n-2).

Part 2 of the teaching output block grant, namely the so-called teaching development grant, is only allocated to institutions with qualification output (all qualifications except doctoral degrees and research masters degrees) below the national teaching output norm. The extent of the underperformance of these institutions in year (n-2) determines the size of this allocation in year $\mathrm{n}$. The worse the performance as far as qualification output is concerned, the bigger the teaching development allocation. Part 2 of the research output block grant, namely the research development grant in year $n$, is similarly allocated only to institutions with research output (approved publications, doctoral degrees and research masters degrees) below the national research output norm in year (n-2). Again, the worse the research performance of an institution, the bigger the research development allocation. This implies that only about $29 \%$ of subsidy funding for 2007/08 has been determined by output measures.

Figure 2

Schematic representation of NFF subsidy part for HE institutions for year n. Amounts refer to HE grants in $2007 / 08$

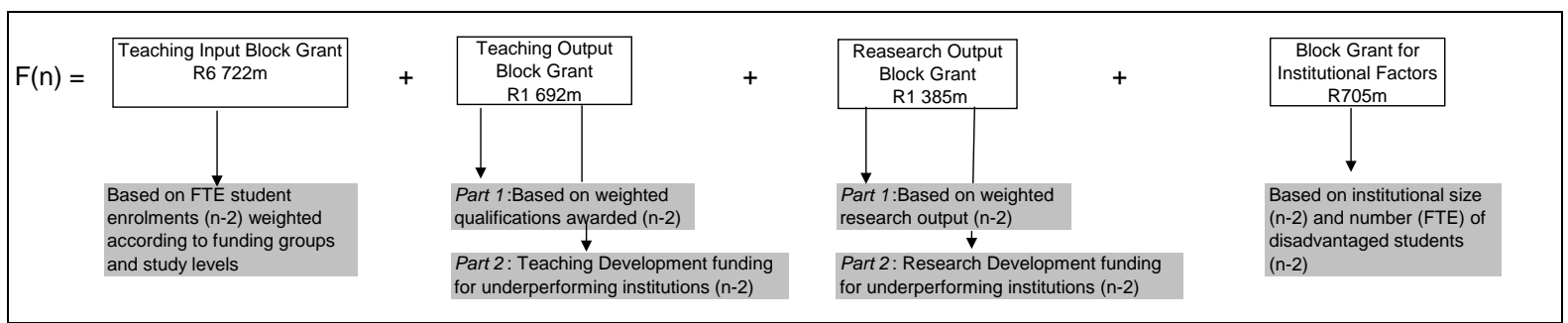


The block grant for institutional factors (only 7\% of the total subsidy in 2007/08) is meant to support small institutions with relatively high fixed costs, as well as institutions with large numbers of disadvantaged students (both financially and educationally). It can be regarded as allocations to institutions to ensure a level playing field for generating the necessary teaching output and research output grants.

As a result of extremely high student growth rates of some HEIs during the years 2002-2004, the teaching input block grant to HEIs was capped with effect from 2005/06.

Jongbloed (2004) makes an interesting classification of public funding of HE along two dimensions, namely the funding base and the degree of market orientation. The funding base relates to the question whether allocations are tied to educational outputs or inputs. The degree of market orientation is linked to whether publicly funded programmes are regulated by central authorities or whether the funding flows are driven by the decisions of the clients (students, private firms, research councils) themselves. In Figure 3 the different subsidy formulas that were used in South Africa are (crudely) classified according to Jongbloed's two-dimensional scheme. For a more complete and substantiated discussion of Figure 3, see Steyn and De Villiers (2007).

\section{Figure 3}

Two-dimensional positioning of HE funding formulas according to Jongbloed's scheme

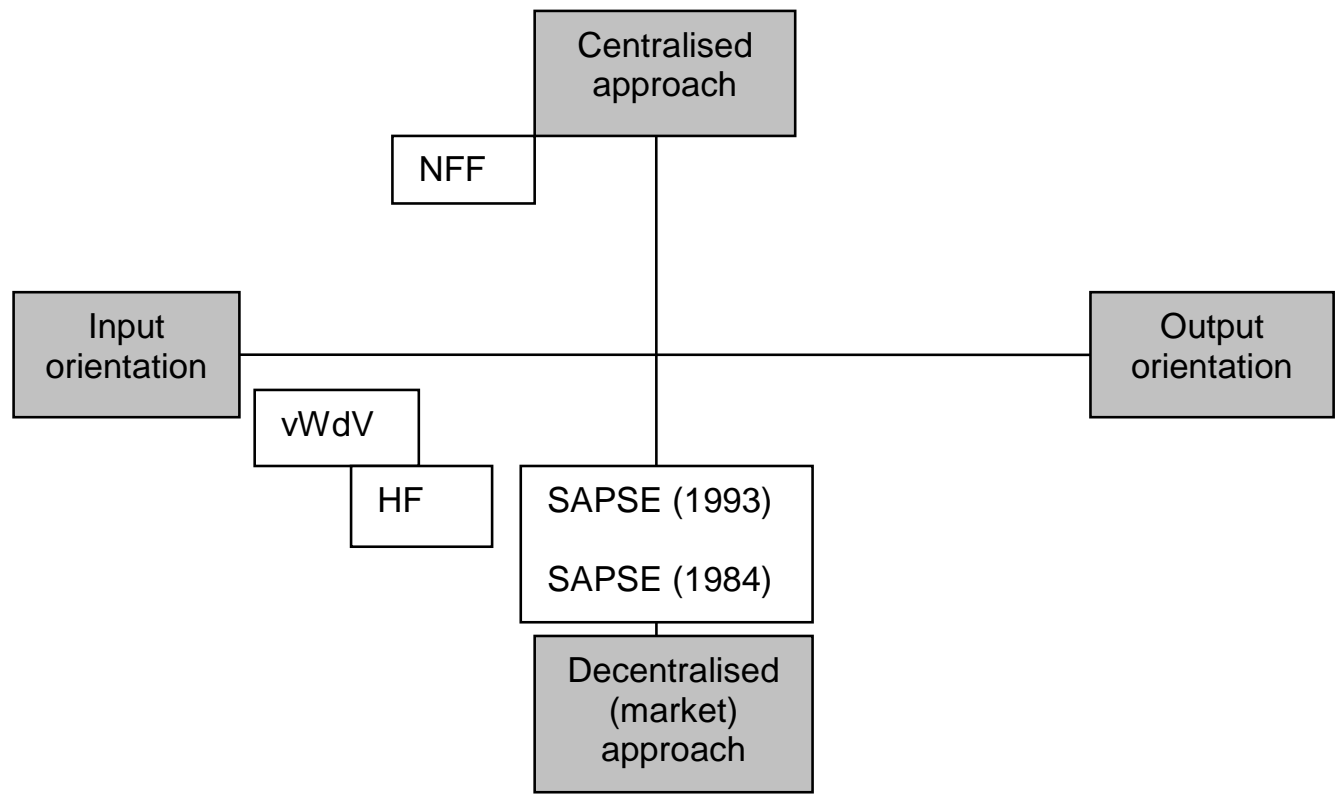




\section{ANALYSIS OF THE OUTPUT OF ALL HE INSTITUTIONS: 1986-2003}

\subsection{Changes in staff and student numbers}

As a result of the decrease in the real value of public spending on $\mathrm{HE}$, academic (instruction/research) staff in this sector did not keep up with the increase in student numbers. This is clearly illustrated in Tables 1 and 2, with the average growth rates of the increase in WFTES shown to be twice as high as the growth rates of FTE instruction/research staff.

At technikons WFTES increased by no less than 344\% from 1986-2003 and FTE instruction/research staff by only 129\%. The same trend is found at universities. At these institution WFTES increased by 96\%, but FTE instruction/research staff by only 31\%.

Table 1

Growth in WFTE students and FTE instruction/research staff at technikons: 1986-2003

\begin{tabular}{|c|c|c|c|c|c|c|c|c|}
\hline \multirow[b]{2}{*}{ Technikon } & \multicolumn{4}{|c|}{ WFTE students } & \multicolumn{4}{|c|}{ FTE instructional/research staff } \\
\hline & 1986 & 1995 & 2003 & $\begin{array}{c}\text { Average annual } \\
\text { growth: 1986-2003 }\end{array}$ & 1986 & 1995 & 2003 & $\begin{array}{c}\text { Average annual } \\
\text { growth: 1986-2003 }\end{array}$ \\
\hline Cape & 4108 & 7391 & 12744 & 7.03 & 259 & 298 & 415 & 2.81 \\
\hline North Gauteng & 596 & 6119 & 10162 & 18.16 & 117 & 173 & 247 & 4.49 \\
\hline Mangosutho & 507 & 3595 & 6249 & 15.92 & 55 & 122 & 161 & 6.52 \\
\hline ML Sultan ${ }^{1)}$ & 2663 & 5105 & - & - & 170 & 255 & - & - \\
\hline Natal $^{1)}$ & 3501 & 6726 & - & - & 241 & 294 & - & - \\
\hline Free State & 1103 & 4888 & 7115 & 11.59 & 77 & 173 & 235 & 6.78 \\
\hline Peninsula & 1895 & 6033 & 7278 & 8.24 & 150 & 333 & 271 & 3.54 \\
\hline Port Elizabeth & 2226 & 6749 & 7119 & 7.08 & 146 & 283 & 305 & 4.43 \\
\hline Pretoria & 6055 & 12910 & 26245 & 9.01 & 432 & 412 & 735 & 3.18 \\
\hline South Africa & 3660 & 31639 & 17098 & 9.49 & 87 & 295 & 695 & 13.00 \\
\hline Vaal Triangle & 2058 & 6944 & 11471 & 10.63 & 176 & 252 & 377 & 4.58 \\
\hline Witwatersrand & 5333 & 8520 & 11272 & 4.50 & 345 & 421 & 670 & 3.98 \\
\hline Border & - & 1270 & 4816 & - & - & 86 & 158 & - \\
\hline North West & - & 1950 & 4267 & - & - & 45 & 159 & - \\
\hline Eastern Cape & - & 2094 & 7345 & - & - & 115 & 131 & - \\
\hline Durban Inst Techn ${ }^{1)}$ & - & - & 16348 & 5.90 & - & - & 603 & 2.28 \\
\hline Total $^{2)}$ & 33615 & 111933 & 149529 & 8.43 & 2251 & 3557 & 5162 & 4.44 \\
\hline $\begin{array}{l}\text { WFTES/FTE } \\
\text { instr/res ratio }\end{array}$ & 14.91 & 31.47 & 28.97 & & & & & \\
\hline
\end{tabular}

1) Technikons ML Sultan and Natal merged in 2003 to form the Durban Institute of Technology. The annual growth rates are calculated by using the total WFTE students and FTE staff for ML Sultan and Natal in 1986.

2) Total annual growth calculated by excluding Border, North West and Eastern Cape, since these institutions were only established in the early eighties and accurate student and staff numbers for 1986 are not available.

This led to an increasing trend in the student/lecturer ratio as shown in Tables 1 and 2. In Figure 4 the WFTES per FTE instruction/research staff member for technikons and universities are shown for the period 1986-2003. As a result of the transition from the SAPSE information system and the HE management information system (HEMIS) during the late 
1990s, no staff statistics are available for 1999. Although there are fairly large fluctuations, the increasing trend in the student/lecturer ratio is evident. For universities the ratio increased from 12.7 in 1986 to 18.0 in 2003 - an increase of 42\%. This increase is even more significant for technikons. The ratio for all technikons increased from 14.9 in 1986 to 29.0 in 2003, which is an increase of $95 \%$. For the HE sector as a whole the above-mentioned ratio increased from 13.1 in 1986 to 20.6 in 2003 - an escalation growth of 57\%. That more was required from lecturers at the end of the period under discussion than in 1986 is self-evident. The next section explores whether this greater burden on lecturers impacted negatively on the teaching and research output of the HE sector.

Table 2

\section{Growth in WFTE students and FTE Instruction/Research staff at universities:}

1986-2003

\begin{tabular}{|c|c|c|c|c|c|c|c|c|}
\hline \multirow[b]{2}{*}{ University } & \multicolumn{4}{|c|}{ WFTE students } & \multicolumn{4}{|c|}{ FTE instructional/research staff } \\
\hline & 1986 & 1995 & 2003 & $\begin{array}{c}\text { Average annual } \\
\text { growth: } 1986-2003\end{array}$ & 1986 & 1995 & 2003 & $\begin{array}{c}\text { Average annual } \\
\text { growth: 1986-2003 }\end{array}$ \\
\hline Cape Town & 10454 & 12879 & 17101 & 2.94 & 1221 & 1336 & 1453 & 1.03 \\
\hline Durban Westville & 5300 & 10114 & 9555 & 3.53 & 420 & 525 & 436 & 0.22 \\
\hline Fort Hare & 2835 & 5463 & 4994 & 3.39 & 232 & 262 & 306 & 1.64 \\
\hline Medunsa & 1019 & 2846 & 2969 & 6.46 & 238 & 315 & 482 & 4.23 \\
\hline Natal & 10123 & 14408 & 21132 & 4.42 & 986 & 1023 & 1324 & 1.75 \\
\hline North & 5125 & 19420 & 8055 & 2.70 & 413 & 492 & 467 & 0.73 \\
\hline Free State & 7354 & 8242 & 15773 & 4.59 & 662 & 659 & 891 & 1.77 \\
\hline Port Elizabeth & 3530 & 4653 & 8130 & 5.03 & 343 & 313 & 355 & 0.19 \\
\hline Potchefstroom & 8031 & 8580 & 16919 & 4.48 & 610 & 583 & 643 & 0.13 \\
\hline Pretoria & 17021 & 21009 & 29518 & 3.29 & 1476 & 1603 & 1839 & 1.30 \\
\hline Rand Afrikaans & 6050 & 12767 & 17710 & 6.52 & 400 & 433 & 1102 & 6.14 \\
\hline Rhodes & 3222 & 4012 & 5751 & 3.47 & 402 & 455 & 337 & -1.03 \\
\hline Unisa & 28623 & 43727 & 49182 & 3.24 & 1220 & 1447 & 1259 & 0.18 \\
\hline Stellenbosch & 11719 & 11959 & 16578 & 2.06 & 1095 & 1072 & 1289 & 0.96 \\
\hline Western Cape & 5643 & 12478 & 10889 & 3.94 & 436 & 718 & 552 & 1.40 \\
\hline Witwatersrand & 15140 & 13884 & 18418 & 1.16 & 1188 & 1422 & 2065 & 3.31 \\
\hline Zululand & 3158 & 7530 & 7282 & 5.04 & 219 & 284 & 260 & 1.01 \\
\hline Vista & 5642 & 21928 & 14599 & 5.75 & 219 & 5906 & 485 & 4.79 \\
\hline Transkei & na & 7816 & 5569 & - & na & 346 & 274 & - \\
\hline North West & na & 3670 & 6388 & - & na & 120 & 254 & - \\
\hline Venda & na & 8280 & 6920 & - & na & 207 & 274 & - \\
\hline Total $^{1)}$ & 149989 & 255665 & 293433 & 3.62 & 11782 & 14205 & 16347 & 1.64 \\
\hline $\begin{array}{l}\text { WFTES/FTE } \\
\text { instr/res ratio }\end{array}$ & 12.73 & 17.99 & 17.95 & & & & & \\
\hline
\end{tabular}

1) Total annual growth calculated by excluding Transkei, North-West and Venda. These institutions' WFTE student and FTE staff numbers are not available for 1986. 
Figure 4

WFTE students per FTE instruction/research staff member for technikons and universities: 1986-2003

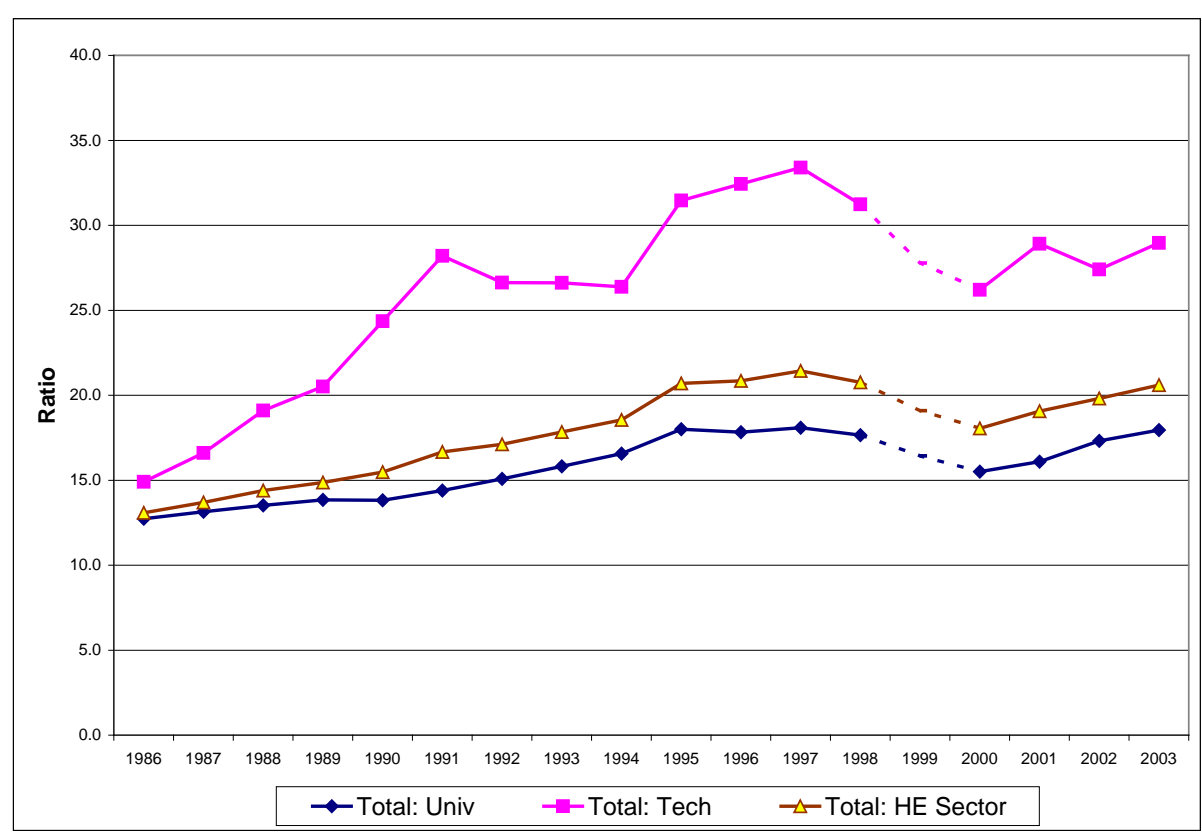

\subsection{Changes in the number of qualifications awarded to students}

The primary purpose of HE institutions is to provide graduates with the skills that the economy requires. The number of qualifications awarded annually by HE institutions is an important measure of their success in doing this. This section sheds some light on the changes in qualifications awarded to students per FTE instruction/research staff member.

From Tables 3 and 4 it is clear that there is an increasing trend in terms of the total number of qualifications awarded per FTE instruction/research staff member in the HE sector of South Africa over time, assuming (for the sake of simplicity) that we give equal weight to all types of qualifications. For technikons the ratio increased by 63\% (equal to an annual growth rate of $3.1 \%$ ) from 3.37 to 5.50 for the period 1987-2003 for all qualifications, while the ratio for the 3-year diplomas increased by $61.4 \%$ over the same time period. The same increasing ratio is also present in the university sector. In this sector the ratio for all qualifications increased by $60.3 \%$ (or on average by $2.81 \%$ per annum) from 3.10 in 1986 to 4.97 in 2003. An increasing trend is also observed for masters degrees awarded per FTE instruction/research staff member at universities for the period under discussion. 
Table 3

Qualifications awarded per FTE instruction/research staff member at technikons: 1987-2003

\begin{tabular}{|l|c|c|c|c|c|c|c|c|}
\hline & \multicolumn{4}{|c|}{ All qualifications } & \multicolumn{4}{c|}{ First 3-year diploma } \\
\hline Technikon & $\mathbf{1 9 8 7}$ & $\mathbf{1 9 9 2}$ & $\mathbf{1 9 9 8}$ & $\mathbf{2 0 0 3}$ & $\mathbf{1 9 8 7}$ & $\mathbf{1 9 9 2}$ & $\mathbf{1 9 9 8}$ & $\mathbf{2 0 0 3}$ \\
\hline Cape & 5.054 & 6.969 & 5.760 & 7.475 & 3.739 & 5.244 & 4.402 & 4.841 \\
\hline North Gauteng & 0.819 & 2.850 & 7.243 & 6.530 & 0.560 & 2.376 & 5.679 & 5.166 \\
\hline Mangosutho & 2.418 & 2.666 & 5.781 & 5.447 & 1.950 & 1.948 & 5.570 & 5.317 \\
\hline ML Sultan $^{1)}$ & 2.289 & 3.040 & 3.405 & - & 1.495 & 2.205 & 2.499 & - \\
\hline Natal $^{1)}$ & 2.515 & 4.975 & 3.741 & - & 1.955 & 3.816 & 2.835 & - \\
\hline Free State & 5.207 & 3.834 & 3.651 & 5.966 & 2.264 & 2.336 & 2.853 & 3.800 \\
\hline Peninsula & 2.283 & 5.413 & 3.707 & 7.834 & 1.317 & 3.991 & 2.668 & 5.137 \\
\hline Port Elizabeth & 3.493 & 3.905 & 5.037 & 6.570 & 2.603 & 3.068 & 3.749 & 3.692 \\
\hline Pretoria & 3.893 & 7.040 & 7.530 & 8.222 & 2.645 & 5.315 & 5.200 & 3.795 \\
\hline South Africa & 1.783 & 5.145 & 14.285 & 1.594 & 0.892 & 4.456 & 12.517 & 0.863 \\
\hline Vaal Triangle & 3.451 & 3.872 & 2.795 & 5.599 & 2.047 & 2.721 & 2.401 & 4.708 \\
\hline Witwatersrand & 4.115 & 5.022 & 3.816 & 2.870 & 2.747 & 3.529 & 2.861 & 1.807 \\
\hline Border & - & - & 2.629 & 4.911 & - & - & 2.521 & 4.278 \\
\hline North West & - & - & 2.804 & 4.107 & - & - & 0.769 & 3.912 \\
\hline Eastern Cape & - & - & 3.340 & 11.481 & - & - & 3.115 & 9.992 \\
\hline Durban Inst Techn ${ }^{1)}$ & - & - & - & 5.196 & - & - & - & 3.839 \\
\hline Total & $\mathbf{3 . 3 7 2}$ & $\mathbf{4 . 8 9 8}$ & $\mathbf{4 . 9 2 7}$ & $\mathbf{5 . 4 9 6}$ & $\mathbf{2 . 2 6 2}$ & $\mathbf{3 . 7 2 8}$ & $\mathbf{3 . 9 4 2}$ & $\mathbf{3 . 6 5 1}$ \\
\hline
\end{tabular}

1) Technikons ML Sultan and Natal merged in 2003 to form the Durban Institute of Technology.

Table 4

Qualifications awarded per FTE instruction/research staff member at universities:

1986-2003

\begin{tabular}{|l|l|l|l|l|l|l|l|l|}
\hline & \multicolumn{3}{|c|}{ All qualifications } & \multicolumn{3}{c|}{ Masters degrees } \\
\hline University & $\mathbf{1 9 8 6}$ & $\mathbf{1 9 9 2}$ & $\mathbf{1 9 9 8}$ & $\mathbf{2 0 0 3}$ & $\mathbf{1 9 8 6}$ & $\mathbf{1 9 9 2}$ & $\mathbf{1 9 9 8}$ & $\mathbf{2 0 0 3}$ \\
\hline Cape Town & 7.529 & 2.814 & 2.827 & 3.511 & 0.216 & 0.276 & 0.344 & 0.432 \\
\hline Durban Westville & 2.621 & 3.370 & 4.184 & 4.296 & 0.083 & 0.161 & 0.078 & 0.411 \\
\hline Fort Hare & 1.213 & 3.929 & 2.605 & 2.876 & 0.034 & 0.031 & 0.003 & 0.062 \\
\hline Medunsa & 0.676 & 1.081 & 1.431 & 1.712 & 0.113 & 0.114 & 0.099 & 0.145 \\
\hline Natal & 2.585 & 3.702 & 4.504 & 5.711 & 0.162 & 0.285 & 0.322 & 0.629 \\
\hline North & 2.206 & 3.548 & 6.267 & 2.255 & 0.015 & 0.005 & 0.010 & 0.084 \\
\hline Free State & 3.006 & 3.252 & 3.321 & 5.065 & 0.329 & 0.407 & 0.395 & 0.588 \\
\hline Port Elizabeth & 2.582 & 3.411 & 4.550 & 8.211 & 0.172 & 0.241 & 0.216 & 0.580 \\
\hline Potchefstroom & 3.487 & 3.748 & 4.189 & 9.370 & 0.238 & 0.264 & 0.355 & 0.866 \\
\hline Pretoria & 2.836 & 3.579 & 4.159 & 4.999 & 0.235 & 0.331 & 0.461 & 0.660 \\
\hline Rand Afrikaans & 4.068 & 5.688 & 11.328 & 5.304 & 0.425 & 0.701 & 0.727 & 0.351 \\
\hline Rhodes & 2.336 & 2.143 & 2.754 & 7.104 & 0.124 & 0.146 & 0.216 & 0.359 \\
\hline Unisa & 4.745 & 5.276 & 9.414 & 10.618 & 0.235 & 0.247 & 0.318 & 0.451 \\
\hline Stellenbosch & 3.003 & 3.079 & 3.645 & 4.084 & 0.323 & 0.371 & 0.589 & 0.690 \\
\hline Western Cape & 2.554 & 4.801 & 2.709 & 4.062 & 0.016 & 0.069 & 0.146 & 0.422 \\
\hline Witwatersrand & 3.262 & 3.092 & 2.999 & 2.002 & 0.377 & 0.264 & 0.448 & 0.275 \\
\hline Zululand & 3.694 & 4.803 & 4.095 & 7.277 & 0.014 & 0.000 & 0.099 & 0.188 \\
\hline Vista & 7.971 & 12.547 & 7.068 & 4.957 & 0.014 & 0.033 & 0.022 & 0.037 \\
\hline Transkei & - & - & 3.514 & 4.942 & - & - & 0.063 & 0.036 \\
\hline North West & - & - & - & 4.374 & - & - & - & 0.193 \\
\hline Venda & - & - & 3.895 & 4.872 & - & - & 0.040 & 0.080 \\
\hline Total & $\mathbf{3 . 1 0 2}$ & $\mathbf{3 . 9 2 8}$ & $\mathbf{4 . 6 3 6}$ & $\mathbf{4 . 9 7 3}$ & $\mathbf{0 . 2 2 0}$ & $\mathbf{0 . 2 5 6}$ & $\mathbf{0 . 3 0 7}$ & $\mathbf{0 . 4 3 9}$ \\
\hline & & & & & & & & \\
\hline
\end{tabular}


In general it does seem as though the change in public funding of HE did not negatively impact on the HE institutions in providing students with the basic qualifications for the economy. One could argue that the HE sector actually became more efficient in delivering trained students to the economy. Note, however, the big variation in the number of qualifications awarded per FTE instruction/research staff member for the HEIs as shown in Tables 3 and 4. Although this is partly the result of fluctuating student enrolments at some institutions, low ratios could also indicate inefficiencies in the teaching processes at some institutions. The one aspect, however, that is not dealt with here is whether academic standards were compromised in the process of increasing the teaching output.

\subsection{Changes in the extent of high-level research in higher education}

The question can be asked whether the increases in student numbers without an accompanying significant increase in academic staff numbers impacted negatively on highlevel research at HE institutions. One way to evaluate the situation is to consider the number of doctoral degrees awarded per FTE instruction/research staff member. The number of doctoral degrees awarded by universities almost doubled from 534 in 1986 to 1024 in $2003 .^{4}$ The increasing trend in doctoral degrees per FTE instructional/research staff member can also be observed in Table 5. However, in 2003 almost 62\% of doctoral degrees were awarded by only 6 institutions. The relatively small number of HE institutions responsible for the majority of these degrees is a cause for concern.

Another, perhaps better, yardstick to measure high-level research is to look at the number of articles published in journals accredited by the Department of Education (also known as publication units) by instruction/research staff. Reliable data on publication units for HE institutions are available only from 1993. During the period 1993-2003 the publication units for universities were on average 5357 and in 2002 an all-time high for the period 1993-2003 of 5606 units was recorded (see Appendix D in Steyn and de Villiers 2006 for a complete series of the data used in this section). Although instruction/research staff members at technikons and universities increased by almost 31\% during 1993-2003, there is no indication of an increasing trend in the total number of publication units over this period. It is true that

\footnotetext{
${ }^{4}$ Doctoral degrees awarded by technikons were disregarded in this analysis, since very few such degrees were awarded by technikons until 2003.
} 
the total number of publication units of technikons increased from a very low base of 55 units in 1993 to 230 in 2003. Although this increasing trend for technikons in the publications per FTE instruction/research staff member is positive, it was still at a low level in 2003.

Table 5

\section{Total number of doctoral degrees awarded and doctoral degrees awarded per FTE} instruction/research staff member at universities: 1986-2003

\begin{tabular}{|l|c|c|c|c|c|c|c|c|}
\hline & \multicolumn{9}{|c|}{ Total number doctoral degrees } & \multicolumn{3}{c|}{$\begin{array}{c}\text { Doctoral degrees per FTE instruction/ } \\
\text { rearch staff member }\end{array}$} \\
\hline University & $\mathbf{1 9 8 6}$ & $\mathbf{1 9 9 2}$ & $\mathbf{1 9 9 8}$ & $\mathbf{2 0 0 3}$ & $\mathbf{1 9 8 6}$ & $\mathbf{1 9 9 2}$ & $\mathbf{1 9 9 8}$ & $\mathbf{2 0 0 3}$ \\
\hline Cape Town & 55 & 74 & 80 & 103 & 0.045 & 0.055 & 0.060 & 0.071 \\
\hline Durban Westville & 0 & 9 & 5 & 46 & 0.000 & 0.018 & 0.011 & 0.106 \\
\hline Fort Hare & 3 & 0 & 0 & 3 & 0.013 & 0.000 & 0.000 & 0.010 \\
\hline Medunsa & 2 & 5 & 6 & 8 & 0.008 & 0.016 & 0.015 & 0.017 \\
\hline Natal & 32 & 38 & 59 & 89 & 0.032 & 0.036 & 0.054 & 0.067 \\
\hline North & 4 & 4 & 0 & 2 & 0.010 & 0.009 & 0.000 & 0.004 \\
\hline Free State & 43 & 45 & 36 & 84 & 0.065 & 0.069 & 0.052 & 0.094 \\
\hline Port Elizabeth & 20 & 26 & 27 & 23 & 0.058 & 0.079 & 0.083 & 0.065 \\
\hline Potchefstroom & 37 & 30 & 49 & 88 & 0.061 & 0.051 & 0.076 & 0.137 \\
\hline Pretoria & 78 & 118 & 111 & 146 & 0.053 & 0.076 & 0.073 & 0.079 \\
\hline Rand Afrikaans & 35 & 56 & 68 & 92 & 0.087 & 0.125 & 0.132 & 0.083 \\
\hline Rhodes & 18 & 20 & 14 & 27 & 0.045 & 0.037 & 0.031 & 0.080 \\
\hline Unisa & 72 & 78 & 85 & 76 & 0.059 & 0.054 & 0.067 & 0.060 \\
\hline Stellenbosch & 65 & 63 & 89 & 112 & 0.059 & 0.055 & 0.084 & 0.087 \\
\hline Western Cape & 1 & 9 & 14 & 27 & 0.002 & 0.014 & 0.20 & 0.049 \\
\hline Witwatersrand & 64 & 75 & 91 & 73 & 0.054 & 0.053 & 0.067 & 0.035 \\
\hline Zululand & 2 & 0 & 6 & 12 & 0.009 & 0.000 & 0.019 & 0.046 \\
\hline Vista & 3 & 8 & 15 & 5 & 0.014 & 0.018 & 0.017 & 0.010 \\
\hline Transkei & - & - & 1 & 1 & - & - & 0.003 & 0.004 \\
\hline North West & - & - & - & 4 & - & - & - & 0.016 \\
\hline Venda & - & - & 0 & 3 & - & - & 0.000 & 0.011 \\
\hline Total & $\mathbf{5 3 4}$ & $\mathbf{6 9 4}$ & $\mathbf{7 5 6}$ & $\mathbf{1 0 2 4}$ & $\mathbf{0 . 0 4 5}$ & $\mathbf{0 . 0 5 2}$ & $\mathbf{0 . 0 5 2}$ & $\mathbf{0 . 0 6 3}$ \\
\hline
\end{tabular}

It is clear from Tables 6 and 7 that high-level research in South Africa was mainly done at universities. The most research, both in terms of total publication units and usually also in terms of publication units per FTE instruction/research staff member, was conducted by the Universities of Cape Town, Natal, Pretoria, Stellenbosch and Witwatersrand. These institutions were responsible for 59-63 per cent of publication units of the HE sector for any specific year for the period 1993-2003. Pouris (2003) determined that the HE sector is responsible for $80 \%$ of the country's visible research output. These five institutions were thus generating almost half of the worthwhile research in South Africa. If the former universities of Free State, RAU and Unisa are added to the list, these 8 institutions produced between 77 and 83 per cent of accredited publications of the HE sector. A relatively small number of HE institutions were thus generating by far the majority of research. 
Table 6

Total number of publication units and publication units per FTE instruction/research staff member at technikons: 1993-2003

\begin{tabular}{|c|c|c|c|c|c|c|c|c|c|}
\hline \multirow[b]{2}{*}{ Technikon } & \multicolumn{4}{|c|}{ Total number publication units } & \multicolumn{4}{|c|}{$\begin{array}{c}\begin{array}{c}\text { Publication units per FTE instruction/ } \\
\text { research staff member }\end{array} \\
\end{array}$} & \multirow{2}{*}{$\begin{array}{c}\text { Average } \\
1993-2003\end{array}$} \\
\hline & 1993 & 1996 & 2000 & 2003 & 1993 & 1996 & 2000 & 2003 & \\
\hline Cape & 24.81 & 29.39 & 10.62 & 20.41 & 0.090 & 0.093 & 0.031 & 0.049 & 0.056 \\
\hline North Gauteng & 0.00 & 2.00 & 3.00 & 4.20 & 0.000 & 0.010 & 0.013 & 0.017 & 0.011 \\
\hline Mangosutho & 0.00 & 0.00 & 0.00 & 5.95 & 0.000 & 0.000 & 0.000 & 0.037 & 0.006 \\
\hline ML Sultan & 0.50 & 0.06 & 5.59 & - & 0.002 & 0.000 & 0.018 & - & - \\
\hline Natal & 5.88 & 14.72 & 26.35 & - & 0.020 & 0.049 & 0.051 & - & - \\
\hline Free State & 2.58 & 17.52 & 12.62 & 21.37 & 0.016 & 0.088 & 0.053 & 0.091 & 0.058 \\
\hline Peninsula & 2.50 & 3.25 & 5.50 & 12.40 & 0.013 & 0.011 & 0.018 & 0.046 & 0.017 \\
\hline Port Elizabeth & 2.48 & 14.38 & 18.53 & 32.22 & 0.010 & 0.048 & 0.059 & 0.106 & 0.054 \\
\hline Pretoria & 9.88 & 11.08 & 47.01 & 59.67 & 0.025 & 0.024 & 0.080 & 0.081 & 0.053 \\
\hline South Africa & 2.00 & 13.00 & 9.33 & 11.40 & 0.006 & 0.056 & 0.021 & 0.016 & 0.025 \\
\hline Vaal Triangle & 4.53 & 1.50 & 10.78 & 4.88 & 0.018 & 0.005 & 0.028 & 0.013 & 0.016 \\
\hline Witwatersrand & 0.00 & 2.17 & 9.14 & 15.70 & 0.000 & 0.005 & 0.014 & 0.023 & 0.012 \\
\hline Border & - & 0.00 & 2.00 & 6.80 & - & 0.000 & 0.014 & 0.043 & - \\
\hline North West & - & 5.00 & 2.00 & 8.20 & - & 0.100 & 0.020 & 0.052 & - \\
\hline Eastern Cape & - & 0.00 & 0.04 & 0.00 & - & 0.000 & 0.000 & 0.000 & - \\
\hline Durban Inst Techn ${ }^{1)}$ & - & - & - & 26.65 & - & - & - & 0.044 & 0.055 \\
\hline Total & 55.16 & 114.07 & 162.51 & 229.85 & 0.018 & 0.030 & 0.033 & 0.045 & 0.030 \\
\hline
\end{tabular}

1) Technikons ML Sultan and Natal merged in 2003 to form the Durban Institute of Technology. The average publication units are calculated by using the total publication units and FTE staff numbers for ML Sultan and Natal in 1993.

Table 7

Total and average number of publication units and publication units per FTE instruction/research staff member at universities: 1993-2003

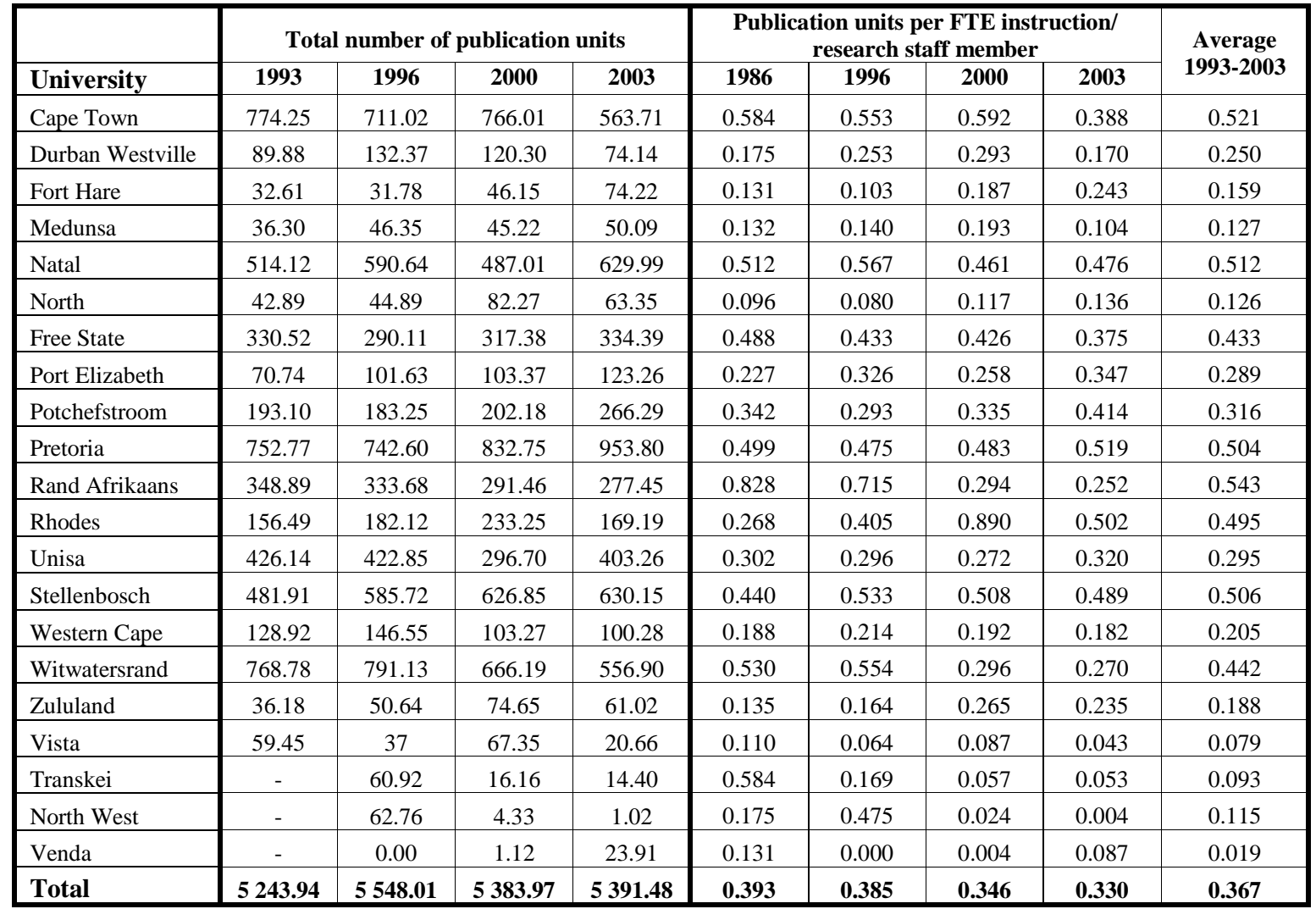


In the analysis of the publication output of HE institutions one must obviously take into account the size of the staff establishment at these institutions. By calculating the publication units per FTE instruction/research staff member, a better picture emerges of whether the higher teaching load has led to a decrease in high-level research activities. Tables 6 and 7 show the situation at technikons and universities respectively. As has already been pointed out, technikons were not responsible for a substantial contribution to publication units. Their situation changed from 1 publication unit per FTE instruction/research staff member at technikons every 56 years in 1993 to 1 publication unit every 22 years by 2003. It is clear that, although the situation had improved, there was still much room for further improvement.

Figure 5

Publication units per FTE instruction/research staff member at HE institutions in South

Africa: 1993-2003

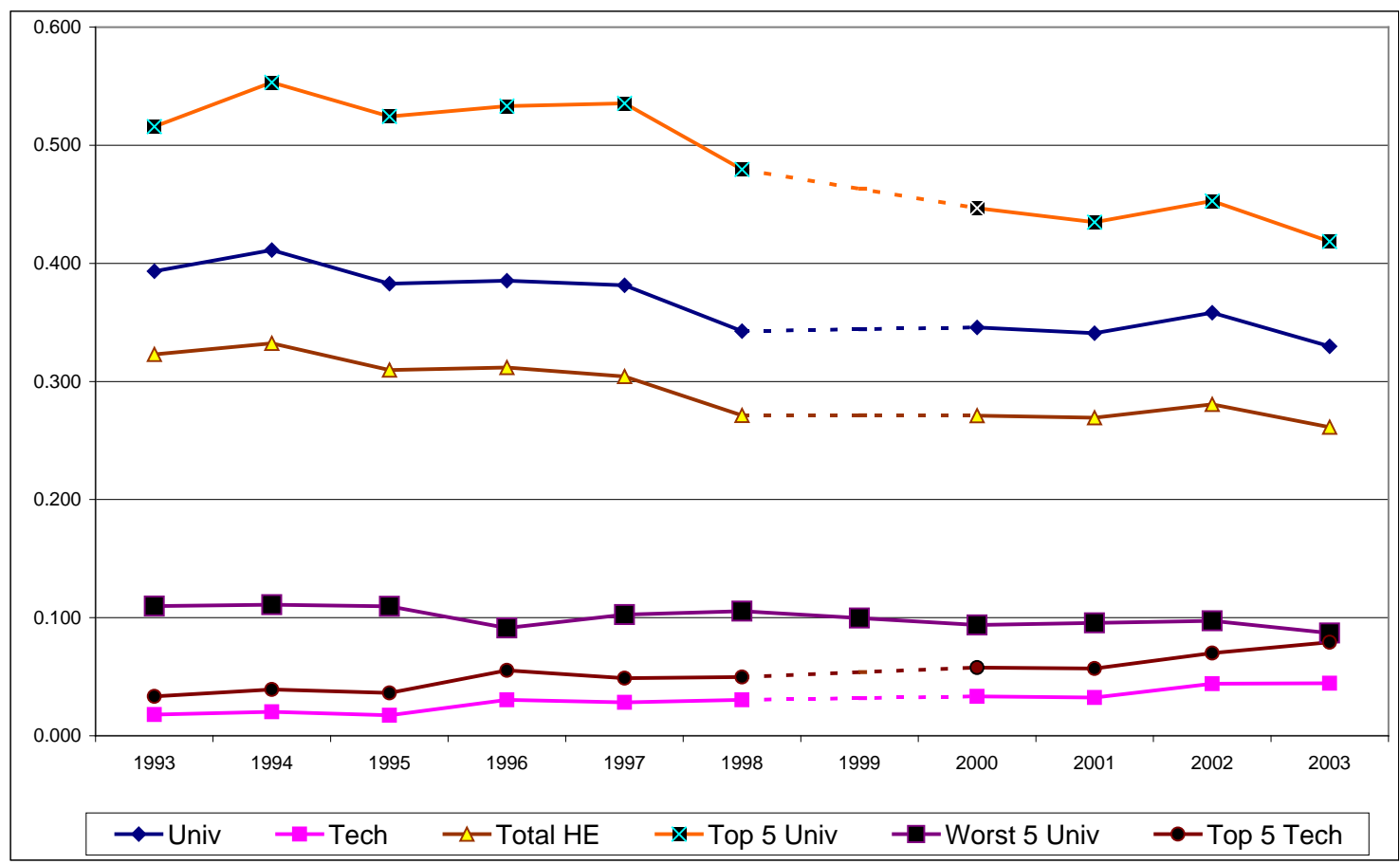

It is important to consider the university sector, where more than $90 \%$ of all publication units of the HE sector were produced. The disturbing fact is that there was no indication of an increasing trend in publication units during the 11 years. Figure 5 shows that the highest number of publication units per FTE instruction/research staff member of 0.411 (translating to 1 article every 2.4 years) was recorded in 1994. After that it decreased to 0.330 in 2003, which means only 1 publication unit every 3 years. If we consider the situation of the 5 universities that were responsible for most of the publication units during 1993-2003, it dropped from 0.553 ( 1 article every 1.8 years) in 1994 to 0.418 ( 1 article every 2.4 years) in 
2003 - a decrease of about $24.4 \%$ in 9 years! This decreasing trend can clearly be observed from Figure 5. It is also interesting to note that the 5 best performing technikons and the 5 worst performing universities in terms of research output per instruction/research staff member were on equal terms in 2003.

A positive aspect for the period 1986-2003 is the steady increase in the number of doctoral degrees awarded at universities, both in terms of total numbers as well as per FTE instruction/research staff member. The challenge is clearly to increase research output in accredited research journals. It is necessary that more funds are made available for the $\mathrm{HE}$ institutions to ensure that more research will be done in those institutions where the most publication units are already generated. It is also necessary to ensure that the increasing student/lecturer ratio does not hamper research activities. The decreasing publication units per lecturer ratio during 1993-2003 is evidence that this was indeed happening.

\section{EARMARKED FUNDING FOR RESEARCH}

In order to ensure that the necessary research will be undertaken in specific or priority areas that are important for a country, most governments have established funding agencies with the necessary expertise to determine worthwhile research projects at HE institutions. In South Africa earmarked allocations for research at HE institutions (by means of various state budget votes) are transferred to the respective agencies and are then distributed amongst $\mathrm{HE}$ institutions by these agencies. The amounts for research in these budget votes are determined by Treasury, usually with no regard whatsoever to the research funding already flowing to HE by means of the education budget. Traditionally the science councils have acted as the agents, and funds were earmarked for basic and strategic research projects or for doctoral studies of promising students at HE institutions. The National Research Foundation (NRF) was established in 1999, replacing the Foundation for Research Development (FRD) and other agencies associated with the science councils which had previously disseminated earmarked research funding. The NRF has already played an important role in the dissemination of project research funding. The scope of earmarked research funding has broadened significantly over the last 10 years. At present the NRF, the Medical Research Council (MRC) and the Water Research Commission (WRC) are responsible for earmarked research allocations to HE institutions. These allocations are a very important part of the third money stream that was already referred to in Section 2.2. 


\section{Figure 6}

\section{Real (constant 2000 prices) earmarked research allocations by state agencies ${ }^{1)}$ to}

universities and technikons 1996-2003 (R'000)

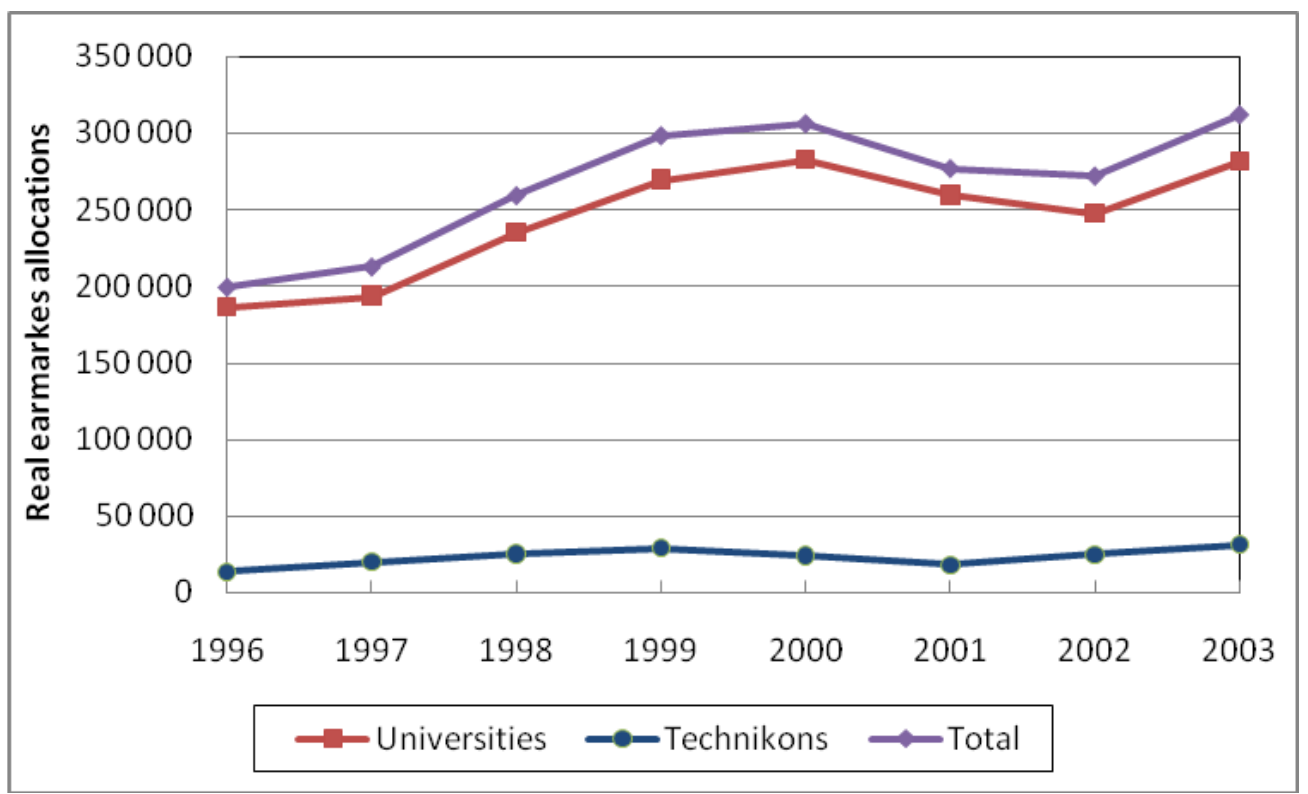

1) WRC allocations excluded

Steyn and De Villiers (2006) studied agency funding for HE institutions for the period 19962003. Their analysis included NRF funding (THRIP allocations, Innovation Fund allocations and some other smaller funding initiatives) and MRC funding. Unfortunately the funding data received from the WRC were too incomplete to include in their study. The WRC contribution to agency funding is, however, relatively small. Figure 6 and Table 8 are based on the data contained in the study by Steyn and De Villiers.

Figure 6 shows that the total nominal amount distributed to universities and technikons, and earmarked for specific research projects chosen according to rather stringent criteria by the NRF and the MRC, increased from R155 million in 1996 to R381 million in 2003. This increase is substantial, even in real terms. The allocations to the technikon sector were rather small when compared to allocations to the university sector. Although the relative position of technikons had improved from 1996 to 2003, universities still received nine times as much as technikons in 2003 as far as NRF and MRC funds were concerned. Understandably there is fierce competition between HE institutions for earmarked research funding. Although the funding allocation criteria used by the NRF and MRC are not based on institutional research performances alone, the performance of the receiving institutions is undoubtedly important. Table 8 shows the total (nominal) allocations from the NRF and MRC to the individual 36 
HE institutions for the years 1996-2003. To measure the best performances by institutions in securing NRF and MRC funding, the average annual nominal allocation per FTE instruction/research staff member was also calculated for each HE institution.

Table 8

Total earmarked research allocations from state agencies for 1996-2003, as well as the average annual allocation per FTE instruction/research staff member according to institution

\begin{tabular}{|c|c|c|}
\hline University & $\begin{array}{c}\text { Total allocation } \\
\text { 1996-2003 } \\
\text { (R'000) }\end{array}$ & $\begin{array}{c}\text { Ave annual alloc }{ }^{1)} \\
\text { per FTE instr/res } \\
\text { (Rand) }\end{array}$ \\
\hline Cape Town & 372672 & 39755 \\
\hline Durban Westville & 47891 & 15336 \\
\hline Fort Hare & 21628 & 11402 \\
\hline Medunsa & 12999 & 4941 \\
\hline Natal & 184309 & 23261 \\
\hline North & 41683 & 10618 \\
\hline Free State & 63217 & 12311 \\
\hline Port Elizabeth & 30175 & 11698 \\
\hline Potchefstroom & 121209 & 27551 \\
\hline Pretoria & 231835 & 20142 \\
\hline Rand Afrikaans & 50685 & 9160 \\
\hline Rhodes & 73467 & 28170 \\
\hline Unisa & 13854 & 1608 \\
\hline Stellenbosch & 313141 & 38591 \\
\hline Western Cape & 108967 & 25490 \\
\hline Witwatersrand & 204772 & 15671 \\
\hline Zululand & 26036 & 12802 \\
\hline Vista & 57525 & 1198 \\
\hline Transkei & 10255 & 4821 \\
\hline North West & 11588 & 8990 \\
\hline Venda & 14185 & 7845 \\
\hline Total & 1960321 & 18360 \\
\hline
\end{tabular}

\begin{tabular}{|l|c|c|}
\hline Technikon & $\begin{array}{c}\text { Total allocation } \\
\text { 1996-2003 } \\
\text { (R'000) }\end{array}$ & $\begin{array}{c}\text { Ave annual alloc } \\
\text { per FTE instr/res } \\
\text { (Rand) }\end{array}$ \\
\hline Cape & 1459 & 7366 \\
\hline North Gauteng & 5283 & 3452 \\
\hline Mangosutho & 1504 & 1450 \\
\hline ML Sultan & 17029 & 7653 \\
\hline Natal & 11461 & 4550 \\
\hline Free State & 25502 & 15984 \\
\hline Peninsula & 18077 & 8606 \\
\hline Port Elizabeth & 27232 & 12596 \\
\hline Pretoria & 39300 & 9853 \\
\hline South Africa & 1622 & 532 \\
\hline Vaal Triangle & 5300 & 2048 \\
\hline Witwatersrand & 8814 & 2130 \\
\hline Border & 2164 & 2182 \\
\hline North West & 1175 & 1632 \\
\hline Eastern Cape & 2398 & 2637 \\
\hline Total & $\mathbf{1 8 5 3 1 9}$ & $\mathbf{5 7 8 0}$ \\
\hline
\end{tabular}

1) Calculated as total nominal allocation for the period 1996-2003 divided by the sum of the FTE instruction/research staff numbers for the same period.

Table 8 shows that, for the university sector, University of Cape Town and Stellenbosch University performed the best in attracting agency funding in the period 1996-2003, while Free State Technikon and Port Elizabeth Technikon attracted the most funds in the technikon sector during this period.

From paragraphs 3 and 4 it is clear that the majority of research activities (in terms of doctoral degrees awarded, articles published in accredited journals and the allocation of research funding) are undertaken by a small number of institutions. In most cases these are the previously advantaged institutions. This has the danger of dividing the HE system into 
two groups of institutions, one that does almost exclusively teaching and the other group that is involved in high level research activities as well.

\section{HE OUTPUT UNDER THE PRESENT SUBSIDY FORMULA}

\subsection{Analysis of output subsidy ratio for 2005-2007}

Although the present formula was applied in 2004 for the first time, official information regarding the breakdown according to institution and the different block grants is not available for 2004. The subsidy output ratios, defined as the ratio of the output subsidy and the sum of the input and output subsidy (as a percentage), are indicated in Table 9 for funding years 2005-2007 for all 23 (post-merger) higher education institutions in the three most recent financial years, namely 2005/06, 2006/07 and 2007/08 (Department of Education, 2007). The output subsidy ratio for the HE system increased significantly from $24.73 \%$ in 2005 to $27.13 \%$ in 2006, but then decreased slightly in 2007. This was mainly the result of a dramatic increase in the total number of publication units of the HE sector from 5621 in 2003 to 7228 in 2005 (keep in mind the 2-year lag in the calculation of state subsidy as outlined in Figure 2).

Table 9

Output subsidy ratios ${ }^{1)}$ for higher education institutions for 2005-2007 according to institution and year

\begin{tabular}{|c|c|c|c|c|c|c|c|c|c|}
\hline \multirow[t]{2}{*}{$\begin{array}{l}\text { Higher Education } \\
\text { Institution }\end{array}$} & $\begin{array}{l}\text { Total input } \\
\text { subsidy } \\
\text { allocation } \\
\text { (R'000) }\end{array}$ & $\begin{array}{l}\text { Total output } \\
\text { subsidy } \\
\text { allocation } \\
\text { (R'000) }\end{array}$ & $\begin{array}{c}\text { Output } \\
\text { ratio } \\
\%\end{array}$ & $\begin{array}{c}\text { Total input } \\
\text { subsidy } \\
\text { allocation } \\
\left(\mathbf{R}^{\prime} 000\right) \\
\end{array}$ & $\begin{array}{l}\text { Total output } \\
\text { subsidy } \\
\text { allocation } \\
\text { (R'000 }\end{array}$ & $\begin{array}{c}\text { Output } \\
\text { ratio } \\
\%\end{array}$ & $\begin{array}{c}\text { Total input } \\
\text { subsidy } \\
\text { allocation } \\
\left(R^{\prime}(000)\right. \\
\end{array}$ & $\begin{array}{l}\text { Total output } \\
\text { subsidy } \\
\text { allocation } \\
\text { (R'000 }\end{array}$ & $\begin{array}{c}\text { Output } \\
\text { ratio } \\
\%\end{array}$ \\
\hline & \multicolumn{3}{|c|}{2005} & \multicolumn{3}{|c|}{2006} & \multicolumn{3}{|c|}{2007} \\
\hline Cape Peninsula UT & 271978 & 76698 & 22.00 & 290879 & 87088 & 23.04 & 312876 & 91528 & 22.63 \\
\hline Cape Town & 311479 & 145540 & 31.85 & 335817 & 168810 & 33.45 & 363332 & 228397 & 38.60 \\
\hline Central UT & 104673 & 26311 & 20.09 & 99863 & 32655 & 24.64 & 108184 & 33876 & 23.85 \\
\hline Durban UT & 252145 & 45656 & 15.33 & 259345 & 58129 & 18.31 & 278718 & 63803 & 18.63 \\
\hline Fort Hare & 82029 & 28475 & 25.77 & 91697 & 21792 & 19.20 & 91886 & 32465 & 26.11 \\
\hline Free State & 279667 & 104834 & 27.27 & 286992 & 107839 & 27.31 & 312396 & 119870 & 27.73 \\
\hline Johannesburg & 414580 & 148920 & 26.43 & 437874 & 181180 & 29.27 & 471833 & 177063 & 27.29 \\
\hline Kwazulu-Natal & 467003 & 212971 & 31.32 & 508699 & 200707 & 28.29 & 547609 & 226348 & 29.25 \\
\hline Limpopo & 243035 & 37419 & 13.34 & 247923 & 43315 & 14.87 & 259436 & 55578 & 17.64 \\
\hline Mangosuthu & 78894 & 11094 & 12.33 & 82286 & 12652 & 13.33 & 87903 & 15530 & 15.01 \\
\hline Nelson Mandela & 219661 & 90490 & 29.18 & 236117 & 111035 & 31.98 & 257249 & 101518 & 28.30 \\
\hline North West & 332569 & 133789 & 28.69 & 332457 & 167877 & 33.55 & 371309 & 151192 & 28.94 \\
\hline Pretoria & 534140 & 242416 & 31.22 & 573867 & 295504 & 33.99 & 620886 & 317260 & 33.82 \\
\hline Rhodes & 71591 & 43454 & 37.77 & 75387 & 52003 & 40.82 & 81563 & 59348 & 42.12 \\
\hline South Africa & 767332 & 179551 & 18.96 & 695690 & 243915 & 25.96 & 794046 & 234104 & 22.77 \\
\hline Stellenbosch & 303711 & 155777 & 33.90 & 326929 & 189039 & 36.64 & 354790 & 197299 & 35.74 \\
\hline Tshwane UT & 541587 & 120823 & 18.24 & 555898 & 154251 & 21.72 & 622616 & 143620 & 18.74 \\
\hline Vaal UT & 167041 & 28420 & 14.54 & 177160 & 32885 & 15.66 & 195726 & 34074 & 14.83 \\
\hline Venda & 98568 & 19040 & 16.19 & 102334 & 19215 & 15.81 & 104497 & 26509 & 20.23 \\
\hline Walter Sisulu & 205309 & 46307 & 18.40 & 217804 & 43587 & 16.67 & 243269 & 35660 & 12.78 \\
\hline Western Cape & 194070 & 51600 & 21.00 & 203534 & 56054 & 21.59 & 213733 & 69671 & 24.58 \\
\hline Witwatersrand & 376948 & 124092 & 24.77 & 397012 & 160009 & 28.73 & 430452 & 172345 & 28.59 \\
\hline Zululand & 92340 & 32218 & 25.87 & 98883 & 30016 & 23.29 & 103198 & 35362 & 25.52 \\
\hline All Institutions & 6410350 & 2105893 & 24.73 & 6634448 & 2469559 & 27.13 & 7227509 & 2622419 & 26.62 \\
\hline
\end{tabular}

1) Output ratio $=(\mathrm{A} /(\mathrm{A}+\mathrm{B})) \times 100 \%$

Where $\mathrm{A}=$ Actual research output block grant + actual teaching output block grant

$\mathrm{B}=$ Teaching input block grant + research development grant + teaching development grant. 
The reason for this was the change in the national policy regarding the calculation of publication units. A new list of accredited journals came into effect in 2004. Many South African journals which had not previously appeared on the list of accredited journals were included in this new list. According to the Academy of Science of South Africa (ASSAf) (2006), many of these journals do not have any international visibility as the articles in these journals are not cited outside of South Africa and many of them are dominated by article contributions from one or two institutions only. The increase in the number of publication units since 2003 is therefore not necessarily an indication of enhanced research performance by the HE sector. The number of publication units in 2004 had therefore become the baseline or new yardstick against which the future number of publication units of the HE sector will be measured.

It is also clear that there are large differences between the output ratios of the 23 institutions in any particular year. Using the output subsidy ratio as a measure of performance in total output (teaching and research combined), the 3 top institutions for the period 2005-2007 were Rhodes (average of 40.2\%), Stellenbosch (average of 35.4\%) and Cape Town (average of $34.6 \%$ ). Seven institutions' output subsidy ratios were lower than $20 \%$. It is clear that output plays a lesser role in the new subsidy formula, which is strange seeing that so much effort is done to improve throughput rates and to stimulate research activities.

\section{$\underline{5.2 \text { Defining output units }}$}

An advantage of the present subsidy formula is that it provides a weighting scheme for the different outputs of higher education institutions. The relative weights of the components of teaching output, namely the different qualifications awarded, as well as the weights of the components of research output as used in the calculation of the respective Parts 1 of the teaching output and research output block grants (see Figure 2), are indicated in Table 10. The associated rand values of each output component in the 2007 financial year are also indicated. 
Table 10

Weights and Rand values of output components ${ }^{1)}$

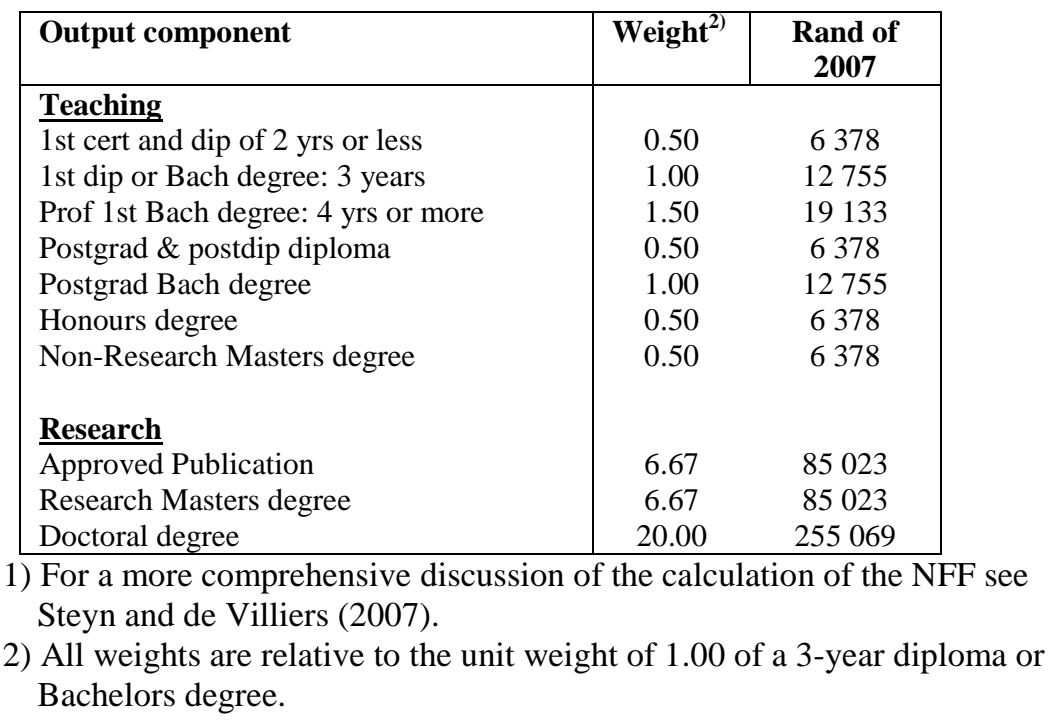

\subsection{An analysis of per capita output units}

Table 10 shows that the weight or subsidy generated by, for example, an awarded doctoral degree is 20 times the weight or subsidy generated by a 3-year bachelor's degree and 40 times the weight or subsidy generated by an honours degree. Furthermore, and a very contentious fact which is presently under revision (see Ministry of Education (2007)), an awarded research masters degree has a weight 13.34 times the weight of an awarded nonresearch masters degree. Given the HE institutions' individual outputs in a particular year, the weights in Table 10 can be used to determine the weighted teaching output units and weighted research output units, as well as the total weighted output units for each $\mathrm{HE}$ institution for that particular year. The total weighted output units therefore measure the number of awarded 3-year degree/diploma equivalents generated each year by an institution.

To determine the improvement of the output of the HE system from year to year, or to compare the output units of individual HE institutions in a particular year, an indicator, namely the weighted output units per FTE instruction/research staff member, can be calculated. Table 11 shows the weighted teaching and research output units per FTE instruction/research staff member, as well as the total weighted output units per FTE instruction/research staff member for all $23 \mathrm{HE}$ institutions from 2002 to 2005. The output data in these 4 years were used in the calculation of the respective output subsidies in 2004 to 
2007 as shown in Figure 2. Note that in the calculation of the weighted output units per FTE instruction/research staff member it was assumed that the mergers between institutions were already effective in 2002 - two years earlier than most of the mergers actually took place. The same student proportions, effective in 2003 when Vista University was unbundled and distributed among 7 institutions, were used in 2002 for the determination of the subsidies and the FTE instruction/research staff numbers for the 7 "merged” institutions.

Table 11

Weighted output units per FTE instruction/research staff member for HE institutions for 2002-2005 according to type of output, institution and year

\begin{tabular}{|c|c|c|c|c|c|c|c|c|c|c|c|c|}
\hline \multirow{3}{*}{$\begin{array}{l}\text { Higher Education } \\
\text { Institution }\end{array}$} & \multicolumn{3}{|c|}{$\begin{array}{c}\text { Weighted output units per FTE } \\
\text { instruction/research staff }\end{array}$} & \multicolumn{3}{|c|}{$\begin{array}{c}\text { Weighted output units per FTE } \\
\text { instruction/research staff }\end{array}$} & \multicolumn{3}{|c|}{$\begin{array}{c}\text { Weighted output units per FTE } \\
\text { instruction/research staff }\end{array}$} & \multicolumn{3}{|c|}{$\begin{array}{l}\text { Weighted output units per FTE } \\
\text { instruction/research staff }\end{array}$} \\
\hline & Research & Teaching & Total & Research & Teaching & Total & Research & Teaching & Total & Research & Teaching & Total \\
\hline & \multicolumn{3}{|c|}{2002} & \multicolumn{3}{|c|}{2003} & \multicolumn{3}{|c|}{2004} & \multicolumn{3}{|c|}{2005} \\
\hline Cape Peninsula UT & 0.58 & 7.42 & 7.99 & 0.84 & 8.51 & 9.36 & 0.80 & 8.61 & 9.41 & 1.10 & 7.81 & 8.90 \\
\hline Cape Town & 6.59 & 2.83 & 9.42 & 5.45 & 3.06 & 8.51 & 6.34 & 3.12 & 9.45 & 8.85 & 3.33 & 12.19 \\
\hline Central UT & 1.16 & 5.82 & 6.98 & 1.53 & 6.35 & 7.88 & 1.60 & 7.85 & 9.45 & 1.26 & 7.99 & 9.26 \\
\hline Durban UT & 0.68 & 4.37 & 5.05 & 0.80 & 5.55 & 6.34 & 0.82 & 7.01 & 7.83 & 0.82 & 7.71 & 8.53 \\
\hline Fort Hare & 1.99 & 3.59 & 5.58 & 1.97 & 2.89 & 4.86 & 1.07 & 4.41 & 5.48 & 1.78 & 5.55 & 7.33 \\
\hline Free State & 6.60 & 3.43 & 10.03 & 5.81 & 3.71 & 9.51 & 4.71 & 3.65 & 8.35 & 5.24 & 4.09 & 9.34 \\
\hline Johannesburg & 3.13 & 4.00 & 7.13 & 3.08 & 3.85 & 6.93 & 3.18 & 4.03 & 7.21 & 2.84 & 4.05 & 6.89 \\
\hline Kwazulu-Natal & 5.16 & 3.49 & 8.65 & 5.99 & 4.28 & 10.27 & 5.45 & 4.11 & 9.56 & 6.29 & 4.13 & 10.41 \\
\hline Limpopo & 1.08 & 1.29 & 2.37 & 1.21 & 2.11 & 3.33 & 1.25 & 2.46 & 3.71 & 1.41 & 3.40 & 4.81 \\
\hline Mangosuthu & 0.04 & 5.94 & 5.99 & 0.25 & 5.51 & 5.76 & 0.19 & 6.04 & 6.22 & 0.12 & 7.21 & 7.34 \\
\hline Nelson Mandela & 2.75 & 4.74 & 7.49 & 3.65 & 7.16 & 10.82 & 3.19 & 7.59 & 10.77 & 4.02 & 7.20 & 11.22 \\
\hline North West & 4.67 & 5.63 & 10.30 & 5.64 & 6.37 & 12.01 & 6.50 & 9.88 & 16.38 & 5.95 & 6.28 & 12.23 \\
\hline Pretoria & 7.67 & 4.64 & 12.30 & 6.58 & 4.34 & 10.93 & 7.69 & 5.06 & 12.75 & 7.56 & 5.44 & 13.00 \\
\hline Rhodes & 8.38 & 4.55 & 12.93 & 7.29 & 7.30 & 14.60 & 9.48 & 4.89 & 14.37 & 10.05 & 5.21 & 15.26 \\
\hline South Africa & 2.76 & 7.18 & 9.94 & 2.44 & 4.54 & 6.98 & 3.66 & 7.72 & 11.38 & 3.75 & 7.42 & 11.17 \\
\hline Stellenbosch & 7.72 & 3.28 & 11.00 & 7.35 & 3.30 & 10.65 & 10.33 & 3.72 & 14.05 & 9.69 & 3.72 & 13.41 \\
\hline Tshwane UT & 0.96 & 7.19 & 8.16 & 0.83 & 8.03 & 8.86 & 0.85 & 8.82 & 9.67 & 0.98 & 7.55 & 8.53 \\
\hline Vaal UT & 0.35 & 4.72 & 5.07 & 0.31 & 5.99 & 6.30 & 0.30 & 6.59 & 6.88 & 0.53 & 5.91 & 6.44 \\
\hline Venda & 0.53 & 2.92 & 3.45 & 1.19 & 4.64 & 5.83 & 0.73 & 5.09 & 5.83 & 1.63 & 6.10 & 7.73 \\
\hline Walter Sisulu & 0.36 & 5.14 & 5.51 & 0.33 & 6.55 & 6.88 & 0.19 & 5.23 & 5.42 & 0.30 & 3.48 & 3.78 \\
\hline Western Cape & 2.83 & 2.93 & 5.76 & 3.64 & 3.58 & 7.22 & 3.98 & 3.59 & 7.58 & 4.73 & 4.19 & 8.93 \\
\hline Witwatersrand & 3.48 & 1.43 & 4.91 & 3.38 & 1.73 & 5.11 & 6.71 & 2.92 & 9.64 & 7.34 & 3.43 & 10.77 \\
\hline Zululand & 3.83 & 3.30 & 7.12 & 3.27 & 7.17 & 10.44 & 4.64 & 5.55 & 10.19 & 3.24 & 7.60 & 10.83 \\
\hline All Institutions & 3.83 & 4.19 & 8.03 & 3.79 & 4.49 & 8.28 & 4.36 & 5.30 & 9.66 & 4.65 & 5.21 & 9.86 \\
\hline
\end{tabular}

Table 12 shows the weighted output units per staff member for the same period for all individual institutions with the difference that the respective weighted output units are divided by the number of permanently appointed instruction/research staff numbers and not the FTE instruction/research staff members at each institution. Since the part-time (and usually temporary) academic staff are included in the FTE instruction/research staff calculation, and part-time staff could in the case of some institutions carry as much as $30 \%$ of the total teaching and research load, dividing the weighted output units by FTE instruction/research staff numbers results in a more accurate measure of relative weighted output. The Department of Education, however, prefers to publish and use permanently appointed instruction/research staff in their analyses of higher education staff data. According to the Department, the headcount numbers of permanently appointed instruction/research staff submitted annually by HE institutions as part of the Higher Education Management 
Information System (HEMIS) is more accurate than the FTE staff numbers submitted in HEMIS.

Table 12

Weighted output units per permanently appointed instruction/research staff member

for HE institutions for 2002-2005 according to type of output, institution and year

\begin{tabular}{|c|c|c|c|c|c|c|c|c|c|c|c|c|}
\hline \multirow{3}{*}{$\begin{array}{l}\text { Higher Education } \\
\text { Institution }\end{array}$} & \multicolumn{3}{|c|}{$\begin{array}{l}\text { Weighted output units per perm } \\
\text { instruction/research staff }\end{array}$} & \multicolumn{3}{|c|}{$\begin{array}{l}\text { Weighted output units per perm } \\
\text { instruction/research staff }\end{array}$} & \multicolumn{3}{|c|}{$\begin{array}{l}\text { Weighted output units per perm } \\
\text { instruction/research staff }\end{array}$} & \multicolumn{3}{|c|}{$\begin{array}{l}\text { Weighted output units per perm } \\
\text { instruction/research staff }\end{array}$} \\
\hline & Research & Teaching & Total & Research & Teaching & Total & Research & Teaching & Total & Research & Teaching & Total \\
\hline & \multicolumn{3}{|c|}{2002} & \multicolumn{3}{|c|}{2003} & \multicolumn{3}{|c|}{2004} & \multicolumn{3}{|c|}{2005} \\
\hline Cape Peninsula UT & 0.72 & 9.24 & 9.96 & 0.97 & 9.75 & 10.72 & 0.99 & 10.66 & 11.66 & 1.42 & 10.13 & 11.56 \\
\hline Cape Town & 11.90 & 5.11 & 17.02 & 10.17 & 5.71 & 15.88 & 11.26 & 5.54 & 16.81 & 15.69 & 5.91 & 21.60 \\
\hline Central UT & 1.85 & 9.31 & 11.16 & 2.32 & 9.62 & 11.94 & 2.16 & 10.63 & 12.79 & 1.78 & 11.30 & 13.08 \\
\hline Durban UT & 0.83 & 5.33 & 6.17 & 0.88 & 6.15 & 7.03 & 0.89 & 7.64 & 8.52 & 0.89 & 8.42 & 9.32 \\
\hline Fort Hare & 2.47 & 4.46 & 6.93 & 3.00 & 4.39 & 7.39 & 1.41 & 5.81 & 7.22 & 2.68 & 8.39 & 11.07 \\
\hline Free State & 8.41 & 4.37 & 12.78 & 7.36 & 4.69 & 12.05 & 8.46 & 6.55 & 15.01 & 8.51 & 6.64 & 15.16 \\
\hline Johannesburg & 5.99 & 7.64 & 13.63 & 6.55 & 8.18 & 14.72 & 6.78 & 8.58 & 15.36 & 6.24 & 8.90 & 15.14 \\
\hline Kwazulu-Natal & 6.34 & 4.29 & 10.64 & 7.52 & 5.36 & 12.88 & 6.62 & 4.99 & 11.61 & 7.40 & 4.86 & 12.26 \\
\hline Limpopo & 1.32 & 1.59 & 2.91 & 1.52 & 2.66 & 4.18 & 1.48 & 2.91 & 4.40 & 1.59 & 3.83 & 5.42 \\
\hline Mangosuthu & 0.05 & 6.36 & 6.41 & 0.27 & 6.04 & 6.31 & 0.20 & 6.56 & 6.77 & 0.14 & 8.20 & 8.34 \\
\hline Nelson Mandela & 4.02 & 6.93 & 10.95 & 4.64 & 9.10 & 13.74 & 4.54 & 10.80 & 15.33 & 5.12 & 9.17 & 14.29 \\
\hline North West & 5.54 & 6.69 & 12.23 & 7.04 & 7.95 & 14.99 & 7.02 & 10.67 & 17.69 & 7.50 & 7.92 & 15.41 \\
\hline Pretoria & 9.16 & 5.54 & 14.71 & 7.93 & 5.23 & 13.16 & 9.12 & 6.01 & 15.13 & 9.19 & 6.61 & 15.79 \\
\hline Rhodes & 8.27 & 4.49 & 12.75 & 7.37 & 7.37 & 14.74 & 9.30 & 4.80 & 14.10 & 10.02 & 5.19 & 15.21 \\
\hline South Africa & 3.92 & 10.20 & 14.12 & 3.64 & 6.76 & 10.40 & 4.70 & 9.91 & 14.60 & 4.72 & 9.32 & 14.03 \\
\hline Stellenbosch & 11.83 & 5.02 & 16.85 & 11.68 & 5.25 & 16.94 & 14.49 & 5.21 & 19.70 & 13.66 & 5.25 & 18.91 \\
\hline Tshwane UT & 1.20 & 8.97 & 10.18 & 1.07 & 10.36 & 11.44 & 1.20 & 12.39 & 13.59 & 1.47 & 11.33 & 12.80 \\
\hline Vaal UT & 0.46 & 6.11 & 6.57 & 0.38 & 7.34 & 7.71 & 0.36 & 7.91 & 8.27 & 0.71 & 7.85 & 8.56 \\
\hline Venda & 0.52 & 2.83 & 3.35 & 1.22 & 4.75 & 5.96 & 0.70 & 4.89 & 5.60 & 1.64 & 6.12 & 7.75 \\
\hline Walter Sisulu & 0.34 & 4.74 & 5.08 & 0.38 & 7.54 & 7.92 & 0.23 & 6.43 & 6.66 & 0.42 & 4.84 & 5.27 \\
\hline Western Cape & 3.69 & 3.82 & 7.51 & 4.54 & 4.46 & 9.00 & 4.93 & 4.45 & 9.38 & 6.23 & 5.52 & 11.75 \\
\hline Witwatersrand & 7.64 & 3.13 & 10.77 & 7.83 & 4.03 & 11.86 & 7.61 & 3.31 & 10.92 & 9.68 & 4.52 & 14.19 \\
\hline Zululand & 4.00 & 3.44 & 7.44 & 3.51 & 7.70 & 11.21 & 5.22 & 6.23 & 11.45 & 3.78 & 8.88 & 12.66 \\
\hline All Institutions & 5.32 & 5.82 & 11.14 & 5.36 & 6.36 & 11.72 & 5.79 & 7.04 & 12.83 & 6.33 & 7.09 & 13.42 \\
\hline
\end{tabular}

It is clear from Tables 11 and 12 that the per capita weighted research output units increased over the four years, with the largest increase occurring between 2003 and 2004. This is partly due to the increase in publication units that has already been discussed in Section 5.1. For both measures the per capita weighted teaching output units also increased. Although the largest increase also occurred between 2003 and 2004, there is no obvious explanation for this. Understandably the per capita total weighted output units also increased.

Institutions have different policies regarding the employment of part-time/temporary academic staff. Furthermore, many institutions and specifically those far from metropolitan areas frequently do not have the opportunity to employ additional part-time lecturers for especially postgraduate courses where specific expertise is sometimes needed. Tables 11 and 12 clearly show these differences. The best performing institutions during the years 20022005 in terms of teaching and research output are given in Table 13. As one would expect universities lead the research output, but due to the high student/instruction research staff member at universities of technology they lead teaching output. 


\section{Table 13}

Best performing higher education institutions for the period 2002-2005 using the average weighted output units per capita as measure according to type of output

\begin{tabular}{|l|l|l|l|}
\hline \multicolumn{2}{|c|}{$\begin{array}{c}\text { Weighted output units per FTE } \\
\text { instruction/research staff }\end{array}$} & \multicolumn{2}{c|}{$\begin{array}{c}\text { Weighted output units per permanent } \\
\text { instruction/research staff }\end{array}$} \\
\hline Research & Teaching & Research & Teaching \\
\hline Rhodes U & Cape Pen UT & Stellenbosch U & Tshwane UT \\
\hline Stellenbosch U & Tshwane UT & Cape Town U & Central UT \\
\hline Pretoria U & North West U & Pretoria U & Cape Pen UT \\
\hline
\end{tabular}

\section{Conclusions}

Higher education has private and social benefits, and studies indicate that it is profitable for both the individual and the state to invest in education. Currently South Africa is lagging behind international trends, if public expenditure as a percentage of GDP is used as a yardstick. Although the situation has deteriorated over the last few years, there are indications that government is increasingly prepared to invest more in higher education. At present this is in the form of earmarked funding for HE infrastructure and the JIPSA initiative. A much higher level of non-earmarked block grant funding of HEIs will, however, be required in order to ensure that tuition fee increases at HEIs could be kept within bounds from year to year.

It was further shown in this paper that the number of WFTES increased at a much faster rate than the number of FTE instruction/research staff. This resulted in a significant increase in the student/lecturer ratio in the HE sector. The number of qualifications awarded per FTE instruction/research staff member increased quite substantially during the total study period of 1986-2007. Assuming that academic standards were maintained during the study period, lecturers thus became more efficient.

As far as high-level research output is concerned, the picture is not quite that rosy. Although the number of doctoral degrees increased over time, problems emerged in translating the doctoral dissertations into research publication units. The number of publication units per FTE instruction/research staff member at the 5 universities with the highest publication output decreased from 0.553 in 1994 to 0.418 in 2003. Because of the adjustment by the Department of Education in 2004 of the instrument measuring the annual number of 
publication units, it is still too early to judge whether the publication rate has been improving significantly since 2004.

The analysis in Section 5 introduces two new aggregated measures of evaluating the output of HEIs. Both these measures are based on the inherent composition of the block grant calculation in the NFF. Firstly, the output ratio is defined and these ratios for an institution can be regarded as a measure of the percentage of direct return (in the form of output) on each subsidy rand invested by government in a particular institution. Secondly, the concept of weighted output units introduced in Sections 5.2 and 5.3 affords the opportunity to calculate annually the weighted output units per staff member for teaching, for research or for teaching and research jointly for each institution. The weights used are in line with the relative importance that government attaches to each type of teaching or each type of research output as defined in the NFF.

The paper indicates that there is large variability between HEIs as far as teaching and research performances are concerned. Furthermore, only a few HEIs have established themselves as research institutions. At the moment the universities of technology (previously known as technikons) and most of the previously disadvantaged universities have not proven themselves as centres where research is a high priority.

The transformation of the higher education sector is of primary concern to government. Great strides have been taken towards equal opportunities in access to higher education. Seventy five percent of all HE enrolments in 2006 were from the African, Coloured or Indian population groups (Department of Education, 2008(1)). Furthermore, the percentage of the doctoral degrees awarded by HE institutions in South Africa to Africans, Coloureds and Indians increased from $29.5 \%$ in 2000 to $43.7 \%$ in 2006 . The comparable percentages for masters degrees awarded are $41.3 \%$ and $49.7 \%$. Respectively $34.9 \%$ and $28.7 \%$ of all doctoral and masters degrees awarded to Africans, Coloureds and Indians in 2006 was awarded by the 3 institutions indicated in Table 13 as the 'best' research universities for the period 2002 to 2005. In 2006 only 16.5\% of the instruction/research staff appointed in a permanent capacity at these 3 institutions were from the African, Coloures and Indian population groups (Department of Education 2008(2)). If a significant number of the graduates mentioned above could be retained at these institutions or (even better) be 
employed in the broader higher education system in a teaching/research capacity, the face of research in HE in South Africa could be fundamentally changed in coming years.

\section{REFERENCES}

Academy of Science of South Africa (ASSAf). 2006. Report on a Strategic Approach to Research Publishing in South Africa. Pretoria

Department of Education. 2007. Information on the State Budget of Higher Education, Annual Report

Department of Education. 2008(1): HEMIS database for years 2000 and 2006. http://www.education.gov.za/dynamic/dynamic.aspx?pageid=326\&dirid=14

Department of Education 2008(2). Education Statistics in South Africa 2006

De Villiers, A.P. and Steyn, A.G.W. 2006. Income and expenditure trends of higher educations institutions in South Africa: 1986-2003. Perspectives in Education, 24(2):35-48

De Villiers, A.P. and Steyn, A.G.W. 2007. The changing face of public financing of higher education, with special reference to South Africa, South African Journal of Economics, 75(1):136-154

Jongbloed, B. 2004 Funding higher education: options, trade-offs and dilemmas, Paper for Fullbright Brainstorm 2004 - New Trends in Higher Education

Ministry of Education. 2007. Ministerial Statement on Higher Education Funding: 2007/8 to $2009 / 10$

OECD. 2004. Education at a Glance. OECD Indicators 2001. http://www1.oecd.org/els/education/ei/eag/

Pouris, A. 2003. South Africa's research publication record: The last ten years. South African Journal of Science, 22(9):1325-1343

Psacharoupoulos, G. and Patrinos, A. 2002. Returns to Investment in Education: A Further Update, World Bank Policy Research Working Paper 2881

Steyn, A.G.W. and de Villiers, A.P. 2006. The impact of changing funding on higher education institutions in South Africa. Higher Education Monitor No. 4, March 2006

Steyn, A.G.W. and de Villiers, A.P. 2007. Public funding of higher education in South Africa by means of a formulae. In Lange, L. and Luescher, T. (Eds). 2007. Review of Higher Education in South Africa. Selected Themes. Pretoria: Council on Higher Education, 1152 
UNESCO Institute of Statistics. 2004. Global Education Digest 2004: Comparing Education Statistics across the World. Montreal 